\title{
US physician tells heroic tale of Moscow
}

THE medical problems of dealing with the victims of the Chernobyl accident hospitalized in Moscow have turned out to be unexpectedly difficult, according to Dr Robert Gale, the Los Angeles physician who had been working at Moscow's Hospital No. 6 until a brief respite last weekend. Dr Gale, speaking on the telephone from Los Angeles earlier this week, said that the 299 patients at the hospital appear all to have received a damaging dose of radiation while working at or near the reactor damaged on 26 April.

According to Dr Gale, typical doses exceeded $2 \mathrm{~Gy}(1 \mathrm{~Gy}=100 \mathrm{rad})$ with the doses received by the most seriously injured workers exceeding $5 \mathrm{~Gy}$. Although most of the radiation exposure appeared to have been caused by gamma rays, Dr Gale explained that the difficulty of treating the patients in Hospital No. 6 arose from the variety of the means by which radiation doses had accumulated. Some people had breathed substantial doses into their lungs, others had ingested radioactive materials while other cases were complicated because the radiation appeared to have come from only one side of the body.

While emphasizing that he had no information about those in or near Chernobyl at the time of the accident apart from those in hospital in Moscow, Dr Gale thought if probable that between 50,000 and 100,000 people among the local population now evacuated would have received doses of radiation or of radioactivity large enough to warrant annual examinations.

Among those acutely injured by radiation, Dr Gale explained, the most common symptoms were gastrointestinal disturbance, liver toxicity and depression of haematopoiesis (blood-cell formation). One of the unexpected difficulties of planning to treat severely injured patients by bone-marrow transplantation had been that of tissue-typing in circumstances where blood-counts were falling rapidly.

Dr Gale's presence in Moscow apparently came about as a consequence of approaches to the Soviet authorities through Dr Armand Hammer, chairman of the Occidental Petroleum Company, and Dr Vincent de Vita, director of the US National Cancer Institute. His offer of help was apparently accepted within 24 hours. He speaks highly of the informality with which he, his colleagues and their equipment were allowed into the Soviet Union. With Dr Gale are two colleagues from the University of California at Los
Angeles, Dr Paul Terasaki and Dr Richard Champlin, and Dr Yair Reissner from the Weizmann Institute in Israel.

Much of the activity in Moscow has been concerned with identifying potential donors from among those covered worldwide by the international transplant registry, which is a listing of people with known histocompatibility characteristics. He said it was impressive that it had been possible to identify donors and to deliver tissue for transplantation to Moscow in between 48 and 72 hours. Even so, he said, most of the 35 transplants performed in recent days had used marrow taken from relatives.

Some of the Moscow patients have also received transplants of fetal liver. He takes the view that the experience gathered in the past few weeks in Moscow will be invaluable in responding to future nuclear catastrophes, accidental or otherwise, and says that he is delighted that the Soviet authorities have agreed to full publication of the data now being gathered. He says that the information becoming available will at least double the extent of the pre-existing database.

On the preparedness of his Soviet colleagues, Dr Gale says it is plain that Soviet physicians had "given thought in advance" to the problems that would be posed by a nuclear accident on the scale of Chernobyl.

He also drew attention to the way in which the nuclear accident had stretched the resources of the international transplant registry. Matching tissue for 35 patients had had to be sought in 15 different countries. The problem of dealing with a larger accident could well be beyond present resources, he said.

Tim Beardsley \& Vera Rich

\section{Academics pledge opposition}

\section{Washington}

LEADERS of a drive to discourage academic scientists and engineers from participating in research on the Strategic Defense Initiative (SDI) brought their case to Washington last week. They delivered a pledge to the White House, signed by more than 3,700 science and engineering professors, not to accept or solicit SDI funds. In addition, 2,800 graduate students signed a similar pledge not to participate in SDI-related projects.

The boycott pledge began early last summer on the campuses of Cornell University and the University of Illinois at Urbana-Champaign. Advocates of the pledge argue that it is fruitless to do research on a project that is "not technically feasible".

Furthermore, they suggest that treating SDI as a partial defence rather than a total nuclear shield against Soviet attack will make SDI merely a new weapon system guaranteed to escalate the arms race. At a press conference held in Washington last week, John Kogut, a physics professor at the University of Illinois at UrbanaChampaign and one of the instigators of the pledge, emphasized that SDI would jeopardize existing arms control agreements, such as the Anti-Ballistic Missile Treaty, and make future agreements more difficult to achieve.

Another consequence of a large funding effort for SDI, according to James Melcher, director of the electromagnetic and electronic system laboratory at Massachusetts Institute of Technology (MIT), is a gradual strangling of the US economy. Melcher sees more and more physicists, engineers and computer scientists being drawn into weapons-related research. At the same time, he fears that corporations are placing less emphasis on developing commercially viable technologies, choosing instead to take a "quick fix" from readily available defence funds.

Although spending on SDI research has increased dramatically in the three years since President Reagan announced the programme, only a small portion of that money has actually arrived at academic institutions. According to figures compiled by the Federation of American Scientists (FAS) for a forthcoming report on SDI spending, teaching institutions have received between two and four per cent of total expenditure on SDI. In 1985. for example, SDI payments to universities totalled $\$ 49.1$ million, compared with total SDI expenditures of $\$ 1,464.8$ million. The SDI Organization has provided funds to 69 US universities so far, with Utah State leading the list, having received $£ 27.5$ million since 1983 . Frank Redd, associate director for Utah State's space engineering centre, says that the bulk of that money comes from existing defence contracts, and was only recently changed to come under the SDI umbrella.

Similarly, Robert Byers, a spokesman for Stanford University, the fourth leading recipient of SDI funds according to FAS figures, explains that the bulk of that money comes from a pre-existing Air Force contract for research on free-electron lasers. But support for the pledge drive was low among physicists at Stanford, only eight of twenty-one faculty members signing the pledge. Joseph Palca 